\title{
USE OF THE FLIPPED CLASSROOM TO DESIGN CREATIVE AND ACTIVE ACTIVITIES IN THE FIELD OF COMPUTER SCIENCE
}

\author{
Ricardo Adán SALAS RUEDA \\ National Autonomous University of Mexico, Institute of Applied Sciences and Technology, \\ Circuito Exterior S/N, Ciudad Universitaria, 04510, Mexico City, Mexico
}

Received 16 May 2019; accepted 14 January 2020

\begin{abstract}
The objective of this quantitative research is to analyze the impact of the flipped classroom in the educational process on computer science considering data science and machine learning. This study proposes the consultation of YouTube videos (before class), collaborative work through $M y S Q L$ software (during class) and individual work through MySQL software (after class) in the database subject. The results of machine learning (linear regression) indicate that school activities before, during and after the class positively influence the assimilation of knowledge and development of skills on the administration of the database. Likewise, data science identifies 6 predictive models on the use of the flipped classroom in the educational process by means of the decision tree technique. Finally, the flipped classroom improves the teaching-learning conditions through the performance of creative and active activities.
\end{abstract}

Keywords: data science, educational process, flipped classroom, higher education, machine learning, teaching-learning.

\section{Introduction}

The use of information and communications technologies (ICTs) in the field of education is causing the creation of new pedagogical models for teaching and learning (Salas-Rueda, 2015; Yelamarthi \& Drake, 2015). For example, the flipped classroom promotes the realization of school activities inside and outside the classroom through technological tools and digital resources (Schneider \& Blikstein, 2016; Shen, 2018).

Educational innovation includes the transformation of students into active agents through the use of ICTs (Chiecher \& Melgar, 2018; Kang \& Es, 2019). Advances in technology facilitate the creation of school activities focused on students (Beisiegel, Mitchell, \& Hill, 2018). In particular, digital tools allow the communication, use and dissemination of information on the Internet (Ramírez Mera \& Barragán López, 2018).

*Corresponding author. E-mails: ricardo.salas@icat.unam.mx; ricardoadansalasrueda@hotmail.com 
Nowadays, teachers use the flipped classroom to increase academic performance and motivate students during the teaching-learning process (Burke \& Fedorek, 2017; Maciejewski, 2016). The advantages of this pedagogical model are related to the realization of creative and active activities in the classroom and the personalization of learning (Kim et al., 2014).

The flipped classroom proposes the revision of audiovisual contents before the face-toface session with the purpose of using the time of the class in the development of creative and active activities (Mason, Rutar Shuman, \& Cook, 2013; Shen, 2018).

In the 21 st century, students demand new pedagogical and technological strategies that facilitate the assimilation of knowledge and development of skills. Thus, this research proposes the consultation of YouTube videos (before class), collaborative work through MySQL software (during class) and individual work through $M y S Q L$ software (after class) in the database subject with the purpose of improving the teaching-learning conditions.

This quantitative study analyzes the use of the flipped classroom in the educational process on computer science considering data science and machine learning. Therefore, the research questions are:

- What is the impact of the flipped classroom in the educational process on the administration of the database considering the use of YouTube videos and MySQL software?

- What are the predictive models on the use of the flipped classroom in the educational process on the administration of the database?

Machine learning allows identifying the linear regression through the training section (50\%, 60\% and $70 \%$ of the sample) to evaluate the impact of the flipped classroom in the educational process. Likewise, the evaluation section (50\%, $40 \%$ and $30 \%$ of the sample) allows knowing the accuracy of the linear regression.

On the other hand, data science allows establishing the predictive conditions between the flipped classroom and educational process (assimilation of knowledge and development of skills on the administration of the database) by means of the decision tree technique.

\section{Flipped classroom}

Nowadays, technology is modifying the form of access, use and processing of information in the educational field (Hevia-Artime \& Fueyo-Gutiérrez, 2018; Salas-Rueda, Jesús Vázquez Estupiñán, \& Lugo-García, 2016). In particular, ICTs allow the construction of educational spaces that facilitate the interaction between the contents of the courses and students (Eschenbrenner \& Fui-Hoon Nah, 2019; Yelamarthi \& Drake, 2015).

The flipped classroom promotes the use of various multimedia resources (e.g., videos and digital readings) before class to facilitate the assimilation of knowledge (Burke \& Fedorek, 2017; Kim \& Ahn, 2018). In fact, the technology allows personalized learning because students consult the audiovisual content of the courses at any time and place (Mason et al., 2013).

Teachers can modify the teaching-learning conditions through the flipped classroom because this pedagogical model allows the creation of dynamic, creative and active activities (Cohen et al., 2016; Maciejewski, 2016). For example, students make presentations and discuss the topics of the courses in the classroom (Dommett, 2018). 
Several authors (e.g., Mason et al., 2013; Maciejewski, 2016; Salinas Martínez et al., 2015; Shen, 2018) have incorporated the flipped classroom in school activities and educational practices.

Jing Shen (2018) proposes the revision of the digital presentations in the house and realization of debates in the face-to-face session with the purpose of improving the teachinglearning process on the search of information in Internet. In the same way, Cohen et al. (2016) used the flipped classroom to facilitate the assimilation of knowledge about the use of digital resources. Even, Dommett (2018) incorporated digital readings and videos into school activities for developing students' skills.

In the field of mathematics, Salinas Martínez et al. (2015) propose the use of videos and massive open online course (MOOC) before the face-to-face session and collaborative work in the classroom. In the same way, Madrid García et al. (2018) incorporated the flipped classroom in the field of mathematics through the consultation of audiovisual materials and digital readings.

The results of the flipped classroom in the engineering courses are the improvement of the academic performance of the students and realization of the active activities in the classroom (Mason et al., 2013). In the same way, the use of digital readings before the faceto-face session and the collaborative work in the classroom improved the educational process on electronics (Kim et al., 2014).

Maciejewski (2016) proposes the consultation of videos and realization of online assessments to facilitate the assimilation of knowledge and development of skills in mathematics. Even, Yelamarthi and Drake (2015) point out that the flipped classroom increases the motivation of students during the educational process related to digital circuits.

The media and technological devices have a significant influence on the development of competences (Bonilla-del-Río, Diego-Mantecón, Lena-Acebo, 2018; Law Schuetz, Biancarosa, \& Goode, 2018). In particular, the flipped classroom is a pedagogical and technological model that favors the active role of the student during the teaching-learning process (Cohen et al., 2016; Kim \& Ahn, 2018).

\section{Method}

This quantitative research analyzes the impact of the flipped classroom in the educational process on computer science considering data science and machine learning. The sample consists of 31 students from the Bachelor of Computer Science (25 men and 6 women) who took the database subject in a Mexican university during the 2015 school year. This degree is taught in the executive mode, therefore, the students study and work. The average age of the participants is 26.64 years.

\subsection{Procedure}

The procedure began with the organization of 5 laboratory practices on the administration of the database considering the flipped classroom (see Table 1). MySQL software allows consulting, updating, storing and deleting the information in the database. 
Table 1. Laboratory practices (source: created by author)

\begin{tabular}{|c|c|c|c|c|}
\hline No. & Topic & Before class & During class & After class \\
\hline 1 & $\begin{array}{l}\text { Creation of the } \\
\text { table }\end{array}$ & $\begin{array}{l}\text { Check YouTube videos } \\
\text { about the creation } \\
\text { of the table in the } \\
\text { database }\end{array}$ & $\begin{array}{l}\text { Use MySQL software } \\
\text { with your partner to } \\
\text { create tables about } \\
\text { products and customers }\end{array}$ & $\begin{array}{l}\text { Use MySQL software } \\
\text { individually to create } \\
\text { tables about suppliers } \\
\text { and branch offices }\end{array}$ \\
\hline 2 & $\begin{array}{l}\text { Storage of } \\
\text { information }\end{array}$ & $\begin{array}{l}\text { Check YouTube videos } \\
\text { about the storage of } \\
\text { information in the } \\
\text { database }\end{array}$ & $\begin{array}{l}\text { Use } M y S Q L \text { software } \\
\text { with your partner to } \\
\text { store the information } \\
\text { of the tables (products } \\
\text { and customers) }\end{array}$ & $\begin{array}{l}\text { Use MySQL software } \\
\text { individually to store the } \\
\text { information in the tables } \\
\text { (suppliers and branch } \\
\text { offices) }\end{array}$ \\
\hline 3 & $\begin{array}{l}\text { Query of } \\
\text { information }\end{array}$ & $\begin{array}{l}\text { Check YouTube videos } \\
\text { about the query of } \\
\text { information in the } \\
\text { database }\end{array}$ & $\begin{array}{l}\text { Use MySQL software } \\
\text { with your partner to } \\
\text { consult the information } \\
\text { of the tables (products } \\
\text { and customers) }\end{array}$ & $\begin{array}{l}\text { Use MySQL software } \\
\text { individually to consult } \\
\text { the information of the } \\
\text { tables (suppliers and } \\
\text { branch offices) }\end{array}$ \\
\hline 4 & $\begin{array}{l}\text { Update of } \\
\text { information }\end{array}$ & $\begin{array}{l}\text { Check YouTube videos } \\
\text { about the update of } \\
\text { information in the } \\
\text { database }\end{array}$ & $\begin{array}{l}\text { Use MySQL software } \\
\text { with your partner to } \\
\text { update the information } \\
\text { in the tables (products } \\
\text { and customers) }\end{array}$ & $\begin{array}{l}\text { Use MySQL software } \\
\text { individually to update } \\
\text { the information in the } \\
\text { tables (suppliers and } \\
\text { branch offices) }\end{array}$ \\
\hline 5 & $\begin{array}{l}\text { Elimination of } \\
\text { information }\end{array}$ & $\begin{array}{l}\text { Check YouTube videos } \\
\text { about the elimination } \\
\text { of information in the } \\
\text { database }\end{array}$ & $\begin{array}{l}\text { Use MySQL software } \\
\text { with your partner } \\
\text { to remove the } \\
\text { information from the } \\
\text { tables (products and } \\
\text { customers) }\end{array}$ & $\begin{array}{l}\text { Use MySQL software } \\
\text { individually to remove } \\
\text { the information from } \\
\text { the tables (suppliers and } \\
\text { branch offices) }\end{array}$ \\
\hline
\end{tabular}

The hypotheses about the consultation of the YouTube videos (before the class) and development of competences are:

- Hypothesis 1 (H1): The consultation of YouTube videos (before the class) positively influences the assimilation of knowledge about the administration of the database;

- Hypothesis 2 (H2): The consultation of YouTube videos (before the class) positively influences the development of skills about the administration of the database.

The hypotheses about the use of MySQL software for collaborative work (during the class) and development of competences are:

- Hypothesis 3 (H3): The use of $M y S Q L$ software for collaborative work (during the class) positively influences the assimilation of knowledge about the administration of the database;

- Hypothesis 4 (H4): The use of $M y S Q L$ software for collaborative work (during the class) positively influences the development of skills about the administration of the database.

The hypotheses about the use of $M y S Q L$ software for individual work (after class) and development of competences are:

- Hypothesis 5 (H5): The use of $M y S Q L$ software for individual work (after class) positively influences the assimilation of knowledge about the administration of the database; 
- Hypothesis 6 (H6): The use of MySQL software for individual work (after class) positively influences the development of skills about the administration of the database.

On the other hand, the predictive models on the use of the flipped classroom in the educational process of computing are:

- Predictive model 1 (PM1) on the consultation of YouTube videos (before the class) and assimilation of knowledge;

- Predictive model 2 (PM2) on the consultation of YouTube videos (before the class) and development of skills;

- Predictive model 3 (PM3) on the use of MySQL software for collaborative work (during class) and knowledge assimilation;

- Predictive model 4 (PM4) on the use of MySQL software for collaborative work (during the class) and development of skills;

- Predictive model 5 (PM5) on the use of MySQL software for individual work (after class) and knowledge assimilation;

- Predictive model 6 (PM6) on the use of $M y S Q L$ software for individual work (after class) and development of skills.

\subsection{Analysis of data}

The RapidMiner tool allows the calculation of machine learning (linear regression) with $50 \%$ $(\mathrm{n}=15), 60 \%(\mathrm{n}=18)$ and $70 \%(\mathrm{n}=21)$ of training to evaluate the research hypothesis. In addition, the RapidMiner tool allows the construction of predictive models on the use of the flipped classroom by means of the decision tree technique.

\subsection{Data collection}

Table 2 shows the measurement instrument (questionnaire) used to collect the information.

Table 2. Questionnaire (source: created by author)

\begin{tabular}{|c|c|c|c|c|c|c|}
\hline No. & Variable & Dimension & Question & Answer & $\mathrm{n}$ & $\%$ \\
\hline \multirow[t]{13}{*}{1} & \multirow{13}{*}{$\begin{array}{l}\text { Student } \\
\text { profile }\end{array}$} & \multirow[t]{2}{*}{ Sex } & \multirow[t]{2}{*}{ 1. Indicate your sex } & Man & 25 & $80.65 \%$ \\
\hline & & & & Woman & 6 & $19.35 \%$ \\
\hline & & \multirow[t]{11}{*}{ Age } & \multirow[t]{11}{*}{ 2. Indicate your age } & 20 years & 0 & $0.00 \%$ \\
\hline & & & & 21 years & 0 & $0.00 \%$ \\
\hline & & & & 22 years & 3 & $9.68 \%$ \\
\hline & & & & 23 years & 3 & $9.68 \%$ \\
\hline & & & & 24 years & 3 & $9.68 \%$ \\
\hline & & & & 25 years & 5 & $16.13 \%$ \\
\hline & & & & 26 years & 2 & $6.45 \%$ \\
\hline & & & & 27 years & 2 & $6.45 \%$ \\
\hline & & & & 28 years & 4 & $12.90 \%$ \\
\hline & & & & 29 years & 3 & $9.68 \%$ \\
\hline & & & & $>29$ years & 6 & $19.35 \%$ \\
\hline
\end{tabular}


End of Table 2

\begin{tabular}{|c|c|c|c|c|c|c|}
\hline No. & Variable & Dimension & Question & Answer & $\mathrm{n}$ & $\%$ \\
\hline \multirow[t]{9}{*}{2} & \multirow{9}{*}{$\begin{array}{l}\text { Flipped } \\
\text { classroom }\end{array}$} & \multirow{3}{*}{$\begin{array}{l}\text { Before the } \\
\text { class }\end{array}$} & \multirow{3}{*}{$\begin{array}{l}\text { 3. The consultation } \\
\text { of YouTube videos } \\
\text { facilitates the } \\
\text { educational process }\end{array}$} & Too much (1) & 15 & $48.39 \%$ \\
\hline & & & & Much (2) & 14 & $45.16 \%$ \\
\hline & & & & Little (3) & 2 & $6.45 \%$ \\
\hline & & \multirow{3}{*}{$\begin{array}{l}\text { During the } \\
\text { class }\end{array}$} & \multirow{3}{*}{$\begin{array}{l}\text { 4. The use of } \\
M y S Q L \text { software } \\
\text { for collaborative } \\
\text { work facilitates the } \\
\text { educational process }\end{array}$} & Too much (1) & 19 & $61.29 \%$ \\
\hline & & & & Much (2) & 10 & $32.26 \%$ \\
\hline & & & & Little (3) & 2 & $6.45 \%$ \\
\hline & & \multirow{3}{*}{$\begin{array}{l}\text { After the } \\
\text { class }\end{array}$} & \multirow{3}{*}{$\begin{array}{l}\text { 5. The use of MySQL } \\
\text { software for individual } \\
\text { work facilitates the } \\
\text { educational process }\end{array}$} & Too much (1) & 18 & $58.06 \%$ \\
\hline & & & & Much (2) & 9 & $29.03 \%$ \\
\hline & & & & Little (3) & 4 & $12.90 \%$ \\
\hline \multirow[t]{6}{*}{3} & \multirow{6}{*}{$\begin{array}{l}\text { Educational } \\
\text { process }\end{array}$} & \multirow{3}{*}{$\begin{array}{l}\text { Assimilation } \\
\text { of } \\
\text { knowledge }\end{array}$} & \multirow{3}{*}{$\begin{array}{l}\text { 6. The flipped } \\
\text { classroom facilitates } \\
\text { the assimilation of } \\
\text { knowledge about the } \\
\text { administration of the } \\
\text { database }\end{array}$} & Too much (1) & 20 & $64.52 \%$ \\
\hline & & & & Much (2) & 8 & $25.81 \%$ \\
\hline & & & & Little (3) & 3 & $9.68 \%$ \\
\hline & & \multirow{3}{*}{$\begin{array}{l}\text { Develop- } \\
\text { ment of } \\
\text { skills }\end{array}$} & \multirow{3}{*}{$\begin{array}{l}\text { 7. The flipped } \\
\text { classroom facilitates } \\
\text { the development } \\
\text { of skills about the } \\
\text { administration of the } \\
\text { database }\end{array}$} & Too much (1) & 20 & $64.52 \%$ \\
\hline & & & & Much (2) & 9 & $29.03 \%$ \\
\hline & & & & Little (3) & 2 & $6.45 \%$ \\
\hline
\end{tabular}

\section{Results}

Below are the results on the impact of the flipped classroom in the educational process on computer science considering data science and machine learning.

The flipped classroom facilitates too much $(n=20,64.52 \%)$, much $(n=8,25.81 \%)$ and little $(\mathrm{n}=3,9.68 \%)$ the assimilation of knowledge about the administration of the database. Also, the flipped classroom facilitates too much $(n=20,64.52 \%)$, much $(n=9,29.03 \%)$ and little $(n=2,6.45 \%)$ the development of skills about the administration of the database.

\subsection{Before the class}

The consultation of YouTube videos facilitates too much $(\mathrm{n}=15,48.39 \%)$, much $(\mathrm{n}=14$, $45.16 \%)$ and little $(\mathrm{n}=2,6.45 \%)$ the educational process (see Table 2$)$. The results of machine learning (linear regression) with 50\% (0.583), 60\% (0.640) and 70\% (0.621) of training indicate that $\mathrm{H} 1$ is accepted. Therefore, the consultation of YouTube videos (before the class) positively influences the assimilation of knowledge about the administration of the database. Likewise, the results of machine learning with $50 \%(0.749), 60 \%(0.710)$ and $70 \%(0.619)$ of training indicate that $\mathrm{H} 2$ is accepted. Therefore, the consultation of YouTube videos (before the class) positively influences the development of skills about the administration of the database (see Table 3). 
Table 3. Use of YouTube videos before the class (source: created by author)

\begin{tabular}{|c|c|c|c|c|}
\hline Hypothesis & Training & Linear regression & Conclusion & Square error \\
\hline \multirow{3}{*}{$\begin{array}{l}\text { Hypothesis 1: } \\
\text { Videos YouTube } \rightarrow \\
\text { assimilation of } \\
\text { knowledge }\end{array}$} & $50 \%$ & $y=0.583 x+0.437$ & Accepted: 0.583 & 0.353 \\
\hline & $60 \%$ & $y=0.640 x+0.390$ & Accepted: 0.640 & 0.396 \\
\hline & $70 \%$ & $y=0.621 x+0.402$ & Accepted: 0.621 & 0.476 \\
\hline \multirow{3}{*}{$\begin{array}{l}\text { Hypothesis 2: } \\
\text { Videos YouTube } \rightarrow \\
\text { development of skills }\end{array}$} & $50 \%$ & $y=0.749 x+0.312$ & Accepted: 0.749 & 0.300 \\
\hline & $60 \%$ & $y=0.710 x+0.335$ & Accepted: 0.710 & 0.301 \\
\hline & $70 \%$ & $y=0.619 x+0.417$ & Accepted: 0.619 & 0.286 \\
\hline
\end{tabular}

The PM1 on the flipped classroom presents 7 conditions with the accuracy of $80.65 \%$ (see Figure 1). For example, if the student considers that the consultation of YouTube videos facilitates too much the educational process and has an age $>24.5$ years then the flipped classroom facilitates too much the assimilation of knowledge about the administration of the database. On the other hand, if the student considers that the consultation of YouTube videos facilitates much the educational process and has an age $>31.5$ years then the flipped classroom facilitates too much the assimilation of knowledge about the administration of the database.

Table 4 shows the conditions of the PM1 on the flipped classroom. For example, if the student considers that the consultation of YouTube videos facilitates too much the educational process and has an age $\leq 23.5$ years then the flipped classroom facilitates too much the assimilation of knowledge about the administration of the database.

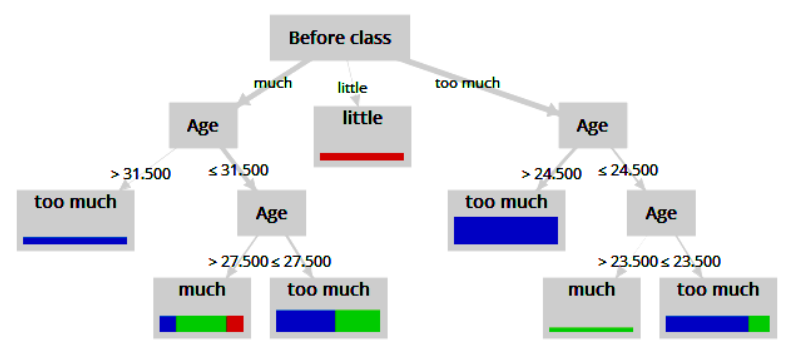

Figure 1. Predictive model 1 on the flipped classroom (source: created by author)

Table 4. Conditions of the predictive model 1 (source: created by author)

\begin{tabular}{|c|c|c|c|c|}
\hline No. & $\begin{array}{c}\text { Videos YouTube } \rightarrow \\
\text { educational process }\end{array}$ & Sex & Age & $\begin{array}{c}\text { Flipped classroom } \rightarrow \\
\text { assimilation of knowledge }\end{array}$ \\
\hline 1 & Much & - & $>31.5$ years & Too much \\
\hline 2 & Much & - & $\leq 31.5 \&>27.5$ years & Much \\
\hline 3 & Much & - & $\leq 27.5$ years & Too much \\
\hline 4 & Little & - & - & Little \\
\hline 5 & Too much & - & $>24.5$ years & Too much \\
\hline 6 & Too much & - & $\leq 24.5 \&>23.5$ years & Much \\
\hline 7 & Too much & - & $\leq 23.5$ years & Too much \\
\hline
\end{tabular}


The PM2 on the flipped classroom presents 7 conditions with the accuracy of $80.65 \%$ (see Figure 2). For example, if the student considers that the consultation of YouTube videos facilitates too much the educational process and has an age $>26.5$ years then the flipped classroom facilitates too much the development of skills about the administration of the database.

On the other hand, if the student considers that the consultation of YouTube videos facilitates much the educational process and has an age $\leq 23$ years then the flipped classroom facilitates too much the development of skills about the administration of the database.

Table 5 shows the conditions of the PM2 on the flipped classroom. For example, if the student considers that the consultation of YouTube videos facilitates too much the educational process and has an age $\leq 25.5$ years then the flipped classroom facilitates too much the development of skills about the administration of the database.

\subsection{During the class}

The use of MySQL software for collaborative work facilitates too much ( $\mathrm{n}=19,61.29 \%$ ), much $(\mathrm{n}=10,32.26 \%)$ and little $(\mathrm{n}=2,6.45 \%)$ the educational process (see Table 2$)$. The results of machine learning with $50 \%(0.632), 60 \%(0.532)$ and $70 \%(0.576)$ of training indicate that H3 is accepted. Therefore, the use of MySQL software for collaborative work (during the class) positively influences the assimilation of knowledge about the administration of the database. Also, the results of machine learning with 50\% (0.517), 60\% (0.475) and 70\% (0.435) of training indicate that $\mathrm{H} 4$ is accepted. Therefore, the use of $M y S Q L$ software for collaborative work (during the class) positively influences the development of skills (see Table 6).

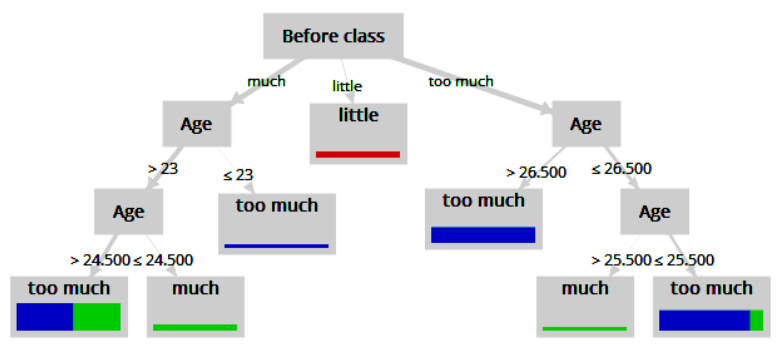

Figure 2. Predictive model 2 on the flipped classroom (source: created by author)

Table 5. Conditions of the predictive model 2 (source: created by author)

\begin{tabular}{|c|c|c|c|c|}
\hline No. & $\begin{array}{c}\text { Videos YouTube } \rightarrow \\
\text { educational process }\end{array}$ & Sex & Age & $\begin{array}{c}\text { Flipped classroom } \rightarrow \\
\text { development of skills }\end{array}$ \\
\hline 1 & Much & - & $>24.5$ years & Too much \\
\hline 2 & Much & - & $\leq 24.5 \&>23$ years & Much \\
\hline 3 & Much & - & $\leq 23$ years & Too much \\
\hline 4 & Little & - & - & Little \\
\hline 5 & Too much & - & $>26.5$ years & Too much \\
\hline 6 & Too much & - & $\leq 26.5 \&>25.5$ years & Much \\
\hline 7 & Too much & - & $\leq 25.5$ years & Too much \\
\hline
\end{tabular}


Table 6.Use of $M y S Q L$ software during the class (source: created by author)

\begin{tabular}{|l|c|c|c|c|}
\hline \multicolumn{1}{|c|}{ Hypothesis } & Training & Linear regression & Conclusion & Square error \\
\hline $\begin{array}{l}\text { Hypothesis 3: } \\
\text { MySQL software } \\
\rightarrow \text { assimilation of } \\
\text { knowledge }\end{array}$ & $50 \%$ & $\mathrm{y}=0.632 \mathrm{x}+0.482$ & Accepted: 0.632 & 0.364 \\
\cline { 2 - 5 } & $60 \%$ & $\mathrm{y}=0.532 \mathrm{x}+0.639$ & Accepted: 0.532 & 0.355 \\
\hline $\begin{array}{l}\text { Hypothesis 4: } \\
\text { MySQL software } \\
\text { development of skills }\end{array}$ & $70 \%$ & $\mathrm{y}=0.576 \mathrm{x}+0.478$ & Accepted: 0.576 & 0.446 \\
\cline { 2 - 5 } & $70 \%$ & $\mathrm{y}=0.517 \mathrm{x}+0.758$ & Accepted: 0.517 & 0.342 \\
\cline { 2 - 5 } & $70 \%$ & $\mathrm{y}=0.475 \mathrm{x}+0.770$ & Accepted: 0.475 & 0.349 \\
\hline
\end{tabular}

The PM3 on the flipped classroom presents 9 conditions with the accuracy of $80.65 \%$ (see Figure 3). For example, if the student considers that the use of $M y S Q L$ software for collaborative work facilitates too much the educational process and has an age $>28.5$ years then the flipped classroom facilitates too much the assimilation of knowledge about the administration of the database. On the other hand, if the student considers that the use of $M y S Q L$ software for collaborative work facilitates much the educational process, is a man and has an age $>28.5$ years then the flipped classroom facilitates too much the assimilation of knowledge about the administration of the database.

Table 7 shows the conditions of the PM3 on the flipped classroom. For example, if the student considers that the use of MySQL software for collaborative work facilitates too much the educational process and has an age $\leq 27.5$ years then the flipped classroom facilitates too much the assimilation of knowledge about the administration of the database.

The PM4 on the flipped classroom presents 9 conditions with the accuracy of $87.10 \%$ (see Figure 4). For example, if the student considers that the use of MySQL software for collaborative work facilitates too much the educational process and has an age $>32.5$ years then the flipped classroom facilitates much the development of skills about the administration of the database. On the other hand, if the student considers that the use of MySQL software for collaborative work facilitates much the educational process and is a woman then the flipped classroom facilitates much the development of skills about the administration of the database.

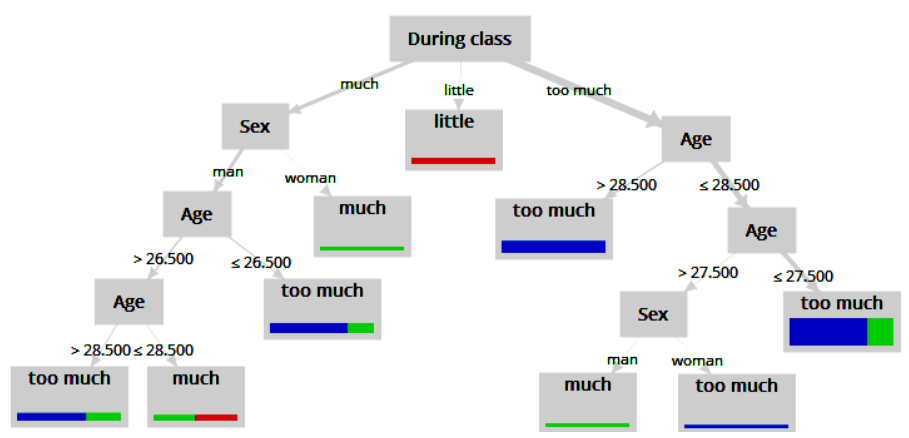

Figure 3. Predictive model 3 on the flipped classroom (source: created by author) 
Table 8 shows the conditions of the PM4 on the flipped classroom. For example, if the student considers that the use of $M y S Q L$ software for collaborative work facilitates too much the educational process and has an age $\leq 28.5$ years then the flipped classroom facilitates too much the development of skills about the administration of the database.

Table 7. Conditions of the predictive model 3 (source: created by author)

\begin{tabular}{|c|c|c|c|c|}
\hline No. & $\begin{array}{c}\text { MySQL software } \rightarrow \\
\text { educational process }\end{array}$ & Sex & Age & $\begin{array}{c}\text { Flipped classroom } \rightarrow \\
\text { assimilation of knowledge }\end{array}$ \\
\hline 1 & Much & Man & $>28.5$ years & Too much \\
\hline 2 & Much & Man & $\leq 28.5 \&>26.5$ years & Much \\
\hline 3 & Much & Man & $\leq 26.5$ years & Too much \\
\hline 4 & Much & Woman & - & Much \\
\hline 5 & Little & - & - & Little \\
\hline 6 & Too much & - & $>28.5$ years & Much \\
\hline 7 & Too much & Man & $\leq 28.5 \&>27.5$ years & Too much \\
\hline 8 & Too much & Woman & $\leq 28.5 \&>27.5$ years & Too much \\
\hline 9 & Too much & - & $\leq 27.5$ years & \\
\hline
\end{tabular}

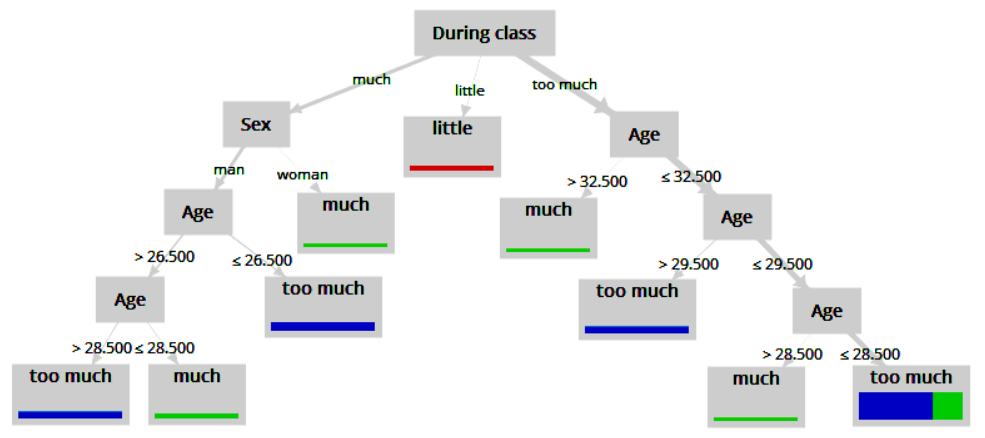

Figure 4. Predictive model 4 on the flipped classroom (source: created by author)

Table 8 . Conditions of the predictive model 4 (source: created by author)

\begin{tabular}{|c|c|c|c|c|}
\hline No. & $\begin{array}{c}\text { MySQL software } \rightarrow \\
\text { educational process }\end{array}$ & Sex & Age & $\begin{array}{c}\text { Flipped classroom } \rightarrow \\
\text { development of skills }\end{array}$ \\
\hline 1 & Much & Man & $>28.5$ years & Too much \\
\hline 2 & Much & Man & $\leq 28.5 \&>26.5$ years & Much \\
\hline 3 & Much & Man & $\leq 26.5$ years & Too much \\
\hline 4 & Much & Woman & - & Much \\
\hline 5 & Little & - & - & Little \\
\hline 6 & Too much & - & $>32.5$ years & Much \\
\hline 7 & Too much & - & $\leq 32.5 \&>29.5$ years & Too much \\
\hline 8 & Too much & - & $\leq 29.5 \&>28.5$ years & Much \\
\hline 9 & Too much & & $\leq 28.5$ years & Too much \\
\hline
\end{tabular}




\subsection{After the class}

The use of $M y S Q L$ software for individual work facilitates too much ( $\mathrm{n}=18,58.06 \%$ ), much $(\mathrm{n}=9,29.03 \%)$ and little $(\mathrm{n}=4,12.90 \%)$ the educational process (see Table 2$)$. The results of machine learning with 50\% (0.271), 60\% (0.289) and 70\% (0.399) of training indicate that H5 is accepted. Therefore, the use of $M y S Q L$ software for individual work (after class) positively influences the assimilation of knowledge about the administration of the database. Likewise, the results of machine learning with 50\% (0.857), 60\% (0.645) and 70\% (0.661) of training indicate that $\mathrm{H} 6$ is accepted. Therefore, the use of $M y S Q L$ software for individual work (after class) positively influences the development of skills about the administration of the database (see Table 9).

The PM5 on the flipped classroom presents 6 conditions with the accuracy of $70.97 \%$ (see Figure 5). For example, if the student considers that the use of MySQL software for individual work facilitates too much the educational process and has an age $\leq 26.5$ years then the flipped classroom facilitates too much the assimilation of knowledge about the administration of the database.

On the other hand, if the student considers that the use of MySQL software for individual work facilitates little the educational process and is a woman then the flipped classroom facilitates little the assimilation of knowledge about the administration of the database.

Table 10 shows the conditions of the PM5 on the flipped classroom. For example, if the student considers that the use of MySQL software for individual work facilitates much the educational process then the flipped classroom facilitates too much the assimilation of knowledge about the administration of the database.

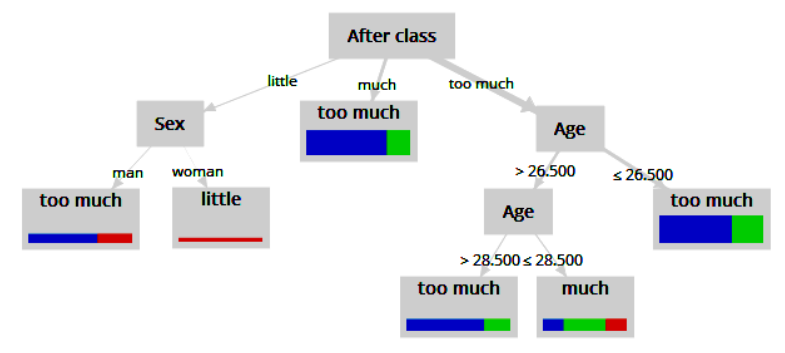

Figure 5. Predictive model 5 on the flipped classroom (source: created by author)

Table 9. Use of $M y S Q L$ software after the class (source: created by author)

\begin{tabular}{|c|c|c|c|c|}
\hline Hypothesis & Training & Linear regression & Conclusion & Square error \\
\hline \multirow{3}{*}{$\begin{array}{l}\text { Hypothesis 5: } \\
\text { MySQL software } \\
\rightarrow \text { assimilation of } \\
\text { knowledge }\end{array}$} & $50 \%$ & $y=0.271 x+0.854$ & Accepted: 0.271 & 0.653 \\
\hline & $60 \%$ & $y=0.289 x+0.105$ & Accepted: 0.289 & 0.659 \\
\hline & $70 \%$ & $y=0.399 x+0.750$ & Accepted: 0.399 & 0.562 \\
\hline \multirow{3}{*}{$\begin{array}{l}\text { Hypothesis 6: } \\
\text { MySQL software } \rightarrow \\
\text { development of skills }\end{array}$} & $50 \%$ & $y=0.857 x+0.380$ & Accepted: 0.857 & 0.662 \\
\hline & $60 \%$ & $y=0.645 x+0.451$ & Accepted: 0.645 & 0.410 \\
\hline & $70 \%$ & $y=0.661 x+0.923$ & Accepted: 0.661 & 0.417 \\
\hline
\end{tabular}


The PM6 on the flipped classroom presents 8 conditions with the accuracy of $77.42 \%$ (see Figure 6). For example, if the student considers that the use of $M y S Q L$ software for individual work facilitates too much the educational process and has an age $>29.5$ years then the flipped classroom facilitates too much the development of skills about the administration of the database. On the other hand, if the student considers that the use of MySQL software for individual work facilitates little the educational process and is a woman then the flipped classroom facilitates little the development of skills about the administration of the database.

Table 11 shows the conditions of the PM6 on the flipped classroom. For example, if the student considers that the use of MySQL software for individual work facilitates too much the educational process and has an age $\leq 26.5$ years then the flipped classroom facilitates too much the development of skills about the administration of the database.

Table 10. Conditions of the predictive model 5 (source: created by author)

\begin{tabular}{|c|c|c|c|c|}
\hline No. & $\begin{array}{c}\text { MySQL software } \rightarrow \\
\text { educational process }\end{array}$ & Sex & Age & $\begin{array}{c}\text { Flipped classroom } \rightarrow \\
\text { assimilation of knowledge }\end{array}$ \\
\hline 1 & Little & Man & - & Too much \\
\hline 2 & Little & Woman & - & Little \\
\hline 3 & Much & - & - & Too much \\
\hline 4 & Too much & - & $>28.5$ years & Too much \\
\hline 5 & Too much & - & $\leq 28.5 \&>26.5$ years & Much \\
\hline 6 & Too much & - & $\leq 26.5$ years & Too much \\
\hline
\end{tabular}

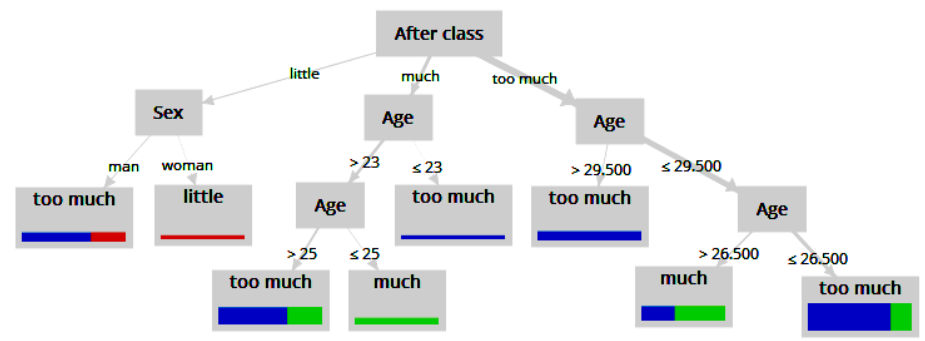

Figure 6. Predictive model 6 on the flipped classroom (source: created by author)

Table 11. Conditions of the predictive model 6 (source: created by author)

\begin{tabular}{|c|c|c|c|c|}
\hline No. & $\begin{array}{c}\text { MySQL software } \rightarrow \\
\text { educational process }\end{array}$ & Sex & Age & $\begin{array}{c}\text { Flipped classroom } \rightarrow \\
\text { development of skills }\end{array}$ \\
\hline 1 & Little & Man & - & Too much \\
\hline 2 & Little & Woman & - & Little \\
\hline 3 & Much & - & $>25$ years & Too much \\
\hline 4 & Much & - & $\leq 25$ years & Much \\
\hline 5 & Much & - & $\leq 23$ years & Too much \\
\hline 6 & Too much & - & $>29.5$ years & Too much \\
\hline 7 & Too much & - & $\leq 29.5 \&>26.5$ years & Much \\
\hline 8 & Too much & - & $\leq 26.5$ years & Too much \\
\hline
\end{tabular}




\section{Discussion}

The flipped classroom is modifying the behavior of students during the teaching-learning process (Kim \& Ahn, 2018; Maciejewski, 2016). In particular, this quantitative research proposes the consultation of YouTube videos (before class), collaborative work through $M y S Q L$ software (during class) and individual work through MySQL software (after class) in the database subject.

Most of the students think that the flipped classroom facilitates too much the assimilation of knowledge $(n=20,64.52 \%)$ and development of skills $(n=20,64.52 \%)$ about the administration of the database.

\subsection{Before the class}

The flipped classroom allows innovating school activities through the incorporation of ICTs (Kim \& Ahn, 2018; Yelamarthi \& Drake, 2015). For example, the consultation of videos before the class favors the active role of the student during the educational process (Burke \& Fedorek, 2017).

Most of the students ( $\mathrm{n}=15,48.39 \%$ ) think that the consultation of YouTube videos facilitates too much the educational process. Also, the result of the linear regression for $\mathrm{H} 1$ is greater than 0.580 , therefore, the consultation of YouTube videos (before the class) positively influences the assimilation of knowledge about the administration of the database. The PM1 on the flipped classroom presents 7 conditions with the accuracy of $80.65 \%$.

Also, the result of the linear regression for $\mathrm{H} 2$ is greater than 0.610 , therefore, the consultation of YouTube videos (before the class) positively influences the development of skills about the administration of the database. The PM2 on the flipped classroom presents 7 conditions with the accuracy of $80.65 \%$.

\subsection{During the class}

This research shares the ideas of various authors (e.g., Maciejewski, 2016; Mason et al., 2013) about the importance of the flipped classroom for the development of competences.

Most of the students ( $\mathrm{n}=19,61.29 \%)$ think that the use of MySQL software for collaborative work facilitates too much the educational process. Also, the result of the linear regression for $\mathrm{H} 3$ is greater than 0.530 , therefore, the use of $M y S Q L$ software for collaborative work (during the class) positively influences the assimilation of knowledge about the administration of the database. The PM3 on the flipped classroom presents 9 conditions with the accuracy of $80.65 \%$.

Also, the result of the linear regression for $\mathrm{H} 4$ is greater than 0.430 , therefore, the use of $M y S Q L$ software for collaborative work (during the class) positively influences the development of skills about the administration of the database. The PM4 on the flipped classroom presents 9 conditions with the accuracy of $87.10 \%$.

\subsection{After the class}

Nowadays, teachers use the flipped classroom to facilitate the assimilation of knowledge and development of skills of students (Maciejewski, 2016; Schneider \& Blikstein, 2016). 
Most of the students $(\mathrm{n}=18,58.06 \%)$ think that the use of $M y S Q L$ software for individual work facilitates too much the educational process. Also, the result of the linear regression for H5 is greater than 0.270, therefore, the use of $M y S Q L$ software for individual work (after class) positively influences the assimilation of knowledge about the administration of the database. The PM5 on the flipped classroom presents 6 conditions with the accuracy of $70.97 \%$.

Also, the result of the linear regression for H6 is greater than 0.640 , therefore, the use of $M y S Q L$ software for individual work (after class) positively influences the development of skills about the administration of the database. The PM6 on the flipped classroom presents 8 conditions with the accuracy of $77.42 \%$.

This research shares the ideas of various authors (e.g., Etchegaray Centeno et al., 2018; Eschenbrenner \& Fui-Hoon Nah, 2019) on the fundamental role of ICTs to meet the demands and needs of students. Finally, the flipped classroom is a pedagogical model that modifies the functions of teachers and the role of students during the educational process through technological tools (Kim et al., 2014; Yelamarthi \& Drake, 2015).

\section{Conclusions}

In the 21st century, the flipped classroom is transforming the organization of courses and realization of activities inside and outside the classroom. Before the class, the students consulted YouTube videos in order to facilitate the assimilation of knowledge and development of skills about the creation of the table and the storage, query, update and elimination of information in the database. In addition, $M y S Q L$ software allows building new educational experiences collaboratively during the class and individually after the class.

This research recommends the use of the flipped classroom in the educational field because teachers can organize creative activities that facilitate the learning process. The limitations of this study are the use of YouTube videos and MySQL software during the educational process of computing. Therefore, future research may analyze the use of social networks, online assessments, digital presentations and Web applications during the realization of activities inside and outside the classroom.

The implications of this research are the use of the flipped classroom in various educational areas such as administration, medicine, marketing and law in order to develop the skills of the students and facilitate the assimilation of knowledge.

Finally, technological advances are changing the functions, activities and roles of teachers and students during the educational process. For example, the flipped classroom facilitates the construction of creative and active educational experiences.

\section{Author contributions}

The flipped classroom improves the teaching-learning conditions through the performance of creative and active activities. This study proposes the consultation of YouTube videos (before class), collaborative work through MySQL software (during class) and individual work through $M y S Q L$ software (after class) in the database subject. 


\section{References}

Beisiegel, M., Mitchell, R., \& Hill, H. C. (2018). The design of video-based professional development: an exploratory experiment intended to identify effective features. Journal of Teacher Education, 69(1), 69-89. https://doi.org/10.1177/0022487117705096

Bonilla-del-Río, M., Diego-Mantecón, J. M., \& Lena-Acebo, F. J. (2018). Estudiantes Universitarios: prosumidores de recursos digitales y mediáticos en la era de internet. Aula Abierta, 47(3), 319-326. https://doi.org/10.17811/rifie.47.3.2018.319-326

Burke, A. S., \& Fedorek, B. (2017). Does "Flipping" promote engagement? A comparison of a traditional, online, and flipped class. Active Learning in Higher Education, 18(1), 11-24. https://doi.org/10.1177/1469787417693487

Chiecher, A. C., \& Melgar, M. F. (2018). Do they know everything? Educational innovations aimed at promoting digital skills in university students. Apertura, 10(2), 1-16. https://doi.org/10.32870/Ap.v10n2.1374

Cohen, M. E., Poggiali, J., Lehner-Quam, A., Wright, R., \& West, R. K. (2016). Flipping the classroom in business and education one-shot sessions: a research study. Journal of Information Literacy, 10(2), 40-63. https://doi.org/10.11645/10.2.2127

Dommett, E. J. (2018). Using a flipped classroom to embed information literacy skills training into academic studies. Journal of Information Literacy, 12(1), 97-108. https://doi.org/10.11645/12.1.2349

Eschenbrenner, B., \& Fui-Hoon Nah, F. (2019). Learning through mobile devices: leveraging affordances as facilitators of engagement. International Journal of Mobile Learning and Organisation, 13(2), 152-170. https://doi.org/10.1504/IJMLO.2019.098193

Etchegaray Centeno, M. C., Duarte Hueros, A. M., \& Guzmán Franco, M. D. (2018). Diseño e integración del recurso multimedia "mine-ducation" en Educación Primaria: Valoraciones aportadas por expertos. Aula Abierta, 47(3), 307-318. https://doi.org/10.17811/rifie.47.3.2018.307-318

Hevia-Artime, I., \& Fueyo-Gutiérrez, A. (2018). Situated learning in the design of virtual learning environments: an experience of peer learning in a community of practice. Aula Abierta, 47(3), 347-354. https://doi.org/10.17811/aula_abierta.47.3.2018.347

Kang, H., \& Es, van E. A. (2019). Articulating design principles for productive use of video in preservice education. Journal of Teacher Education, 70(3), 237-250. https://doi.org/10.1177/0022487118778549

Kim, Y., \& Ahn, Ch. (2018). Effect of combined use of flipped learning and inquiry-based learning on a system modeling and control course. IEEE Transactions on Education, 61(2), 136-142. https://doi.org/10.1109/TE.2017.2774194

Kim, G. J., Patrick, E. E., Srivastava, R., \& Law, M. E. (2014). Perspective on Flipping Circuits I. IEEE Transactions on Education, 57(3), 188-192. https://doi.org/10.1109/TE.2014.2298218

Law Schuetz, R., Biancarosa, G., \& Goode, J. (2018). Is technology the answer? Investigating students' engagement in math. Journal of Research on Technology in Education, 50(4), 318-332. https://doi.org/10.1080/15391523.2018.1490937

Maciejewski, W. (2016). Flipping the calculus classroom: an evaluative study. Teaching Mathematics and Its Applications, 35, 187-201. https://doi.org/10.1093/teamat/hrv019

Madrid García, E. M., Angulo Armenta, J., Prieto Méndez, M. E., Fernández Nistal, M. T., \& Olivares Carmona, K. M. (2018). Implementación de aula invertida en un curso propedéutico de habilidad matemática en bachillerato. Inicio, 10(1). https://doi.org/10.32870/Ap.v10n1.1149

Implementación de aula invertida en un curso propedéutico de habilidad matemática en bachillerato. Apertura, 10(1), 24-39.

Mason, G. S., Rutar Shuman, T., \& Cook, K. E. (2013). Comparing the effectiveness of an inverted classroom to a traditional classroom in an upper-division engineering course. IEEE Transactions on Education, 56(4), 430-435. https://doi.org/10.1109/TE.2013.2249066 
Ramírez Mera, U. N., \& Barragán López, J. F. (2018). University students' self-perception on the use of digital technologies for learning. Apertura, 10(2), 1-21. https://doi.org/10.32870/Ap.v10n2.1401

Salas-Rueda, R. A. 2015. Usable Web interface: technological tool for teaching-learning. Revista de Comunicación de la SEECI, 19(36), 163-177.

Salas-Rueda, R. A., Jesús Vázquez Estupiñán, De J., \& Lugo-García, J. L. (2016). Avatar use in the process of learning on applications of derivatives. Revista de Comunicación de la SEECI, 20(39), 72-88. https://doi.org/10.15198/seeci.2016.39.72-88

Salinas Martínez, P., Quintero Rodríguez, E., \& Rodríguez-Arroyo, J. A. (2015). Curso híbrido y de aula invertida apoyado en MOOC: experiencia de autoevaluación. Apertura: Revista de Innovación Educativa, 7(1), 50-63.

Schneider, B., \& Blikstein, P. (2016). Flipping the flipped classroom: a study of the effectiveness of video lectures versus constructivist exploration using tangible user interfaces. IEEE Transactions on Learning Technologies, 9(1), 5-17. https://doi.org/10.1109/TLT.2015.2448093

Shen, J. (2018). Flipping the classroom for information literacy instruction: considerations towards personalisation and collaborative learning. Journal of Information Literacy, 12(1), 48-67. https://doi.org/10.11645/12.1.2274

Yelamarthi, K., \& Drake, E. (2015). A flipped first-year digital circuits course for engineering and technology students. IEEE Transactions on Education, 58(3), 179-186.

https://doi.org/10.1109/TE.2014.2356174

\title{
ATVIRKŠTINIO MOKYMOSI PANAUDOJIMAS MODELIUOJANT KÜRYBINĘ IR AKTYVIĄJĄ VEIKLĄ KOMPIUTERIŲ MOKSLO SRITYJE
}

\author{
Ricardo Adán SALAS RUEDA
}

\begin{abstract}
Santrauka
Šio kiekybinio tyrimo tikslas - išanalizuoti atvirkštinio mokymosi poveiki kompiuterių mokslui ugdymo proceso metu, remiantis duomenų mokslu ir mašininiu mokymusi. Šiame tyrime duomenų bazėje siūloma pasitelkti YouTube vaizdo įrašus (iki mokymosi proceso), bendradarbiavimu grindžiamą veiklą, naudojantis $M y S Q L$ programine įranga (mokymosi proceso metu) ir individualią veiklą, taikant $M y S Q L$ programinę įrangą (pasibaigus mokymosi procesui). Mašininio mokymosi rezultatai (linijinè regresija) rodo, kad mokyklinè veikla iki mokymosi proceso, jo metu ir jam pasibaigus daro teigiamą ịtaką žinių ịsisavinimui bei duomenų bazès administravimo igūdžių tobulinimui. Panašiai ir duomenų mokslo atveju, remiantis sprendimų medžio metodu, ugdymo proceso metu pasitelkus atvirkštinį mokymąsi, nustatomi 6 prognostiniai modeliai. Galiausiai atvirkštinis mokymasis, taikant kūrybinę ir aktyviąją veiklą, pagerina mokymo-mokymosi sąlygas.
\end{abstract}

Reikšminiai žodžiai: duomenų mokslas, ugdymo procesas, atvirkštinis mokymasis, aukštasis išsilavinimas, mašininis mokymasis, mokymas-mokymasis. 